\title{
SISTEM INFORMASI AKADEMIK PADA SMP NEGERI 1 SOE BERBASIS WEB
}

\author{
Indranata U. Panggalo1*, Christa E. B. Bire ${ }^{2}$, Inosensia V.. H. Laran ${ }^{3}$ \\ 1,2 Politeknik Negeri Kupang \\ Jl. Adi Sucipto Penfui Kupang - NTT. P.O.Box. 139 \\ EE-mail: indrapanggalo@gmail.com \\ christa.eren@gmail.com \\ jhekoml@gmail.com
}

\begin{abstract}
Abstrak
Pemanfaatan Teknologi Informasi dalam pengolahan data dan kecepatan penyampaian informasi saat ini, merupakan sebuah keniscayaan karena setiap institusi maupun lembaga tertuntut untuk memberikan pelayanan secara maksimal kepada setiap stakeholder, tidak terkecuali SMP Negeri 1 soe. Manajemen pengolahan data akademik pada sekolah tersebut belumlah terintegrasi kedalam sebuah sistem sehingga prosesnya menjadi rumit, disamping itu data menjadi sangat rawan terhadap redundansi yang tidak konsisten/sinkron, maupun rawan terhadap manipulasi data oleh staf/orang yang tidak bertanggungjawab. Oleh karena itu kami peneliti membuat sebuah penelitian pengembangan manajeman sistem akademik pada SMPN 1 Soe kedalam sebuah Sistem Informasi Akademik yang berbasis web. Metode pengembangan sistem ini dengan menerapkan salah satu metode pengembangan perangkat lunak yaitu metodewaterfall. Adapun tujuan output yang dapat dihasilkan oleh sistem ini adalah data guru dan siswa, data kelas beserta wali kelas, data mata pelajaran, jadwal mata pelajaran, data nilai tiap siswa dan pencetakan nilai rapot siswa. Setelah dilakukan pengembangan menggunakan bahasa pemrograman PHP dan MySql, maka sistem ini berhasil dibuat dan dapat menampilkan informasi-informasi yang diharapkan sesuai dengan tujuan pengembangan.
\end{abstract}

Kata kunci: Sistem Informasi, Akademik, Web.

\section{PENDAHULUAN}

Teknologi zaman sekarang sangat memungkinkan sebuah informasi dapat diakses dalam waktu nyata (realtime). Informasi dapat diaksesdimanapun dan kapanpun tanpa dibatasi ruang dan waktu. Perkembangan ilmu pengetahuan dan teknologi khususnya teknologi informasi semakin pesat di segala bidang kehidupan. Teknologi informasi mempermudah, mempercepat, serta merapikan pekerjaan yang sebelumnya mengalami banyak keterbatasan.

Dunia pendidikan tak luput dari kebutuhan akan teknologi informasi. Teknologi informasi tidak hanya merupakan kebutuhan yang sangat vital bagi semua institusi pendidikan, akan tetapi juga memberikan nilai lebih bagi institusi tersebut.

Hal-hal di atas menjadikan motivasi bagi penulis untuk membangun sebuah sistem yang dibutuhkan oleh institusi pendidikan dalam membantu proses administrasi akademik. Sistem informasi akademik sangat penting digunakan sebagai pusat informasi bagi sekolah agar dapat selalu memantau perkembangan kegiatan di dalam sekolah tanpa perlu hadir secara fisik sehingga setiap proses dapat dilakukan secara efektif dan efisien.

Sistem akademik yang berjalan pada SMPNegeri 1 SOE mempunyai proses pengolahan data yang belum terintegrasi. Aplikasi yang digunakan untuk penyimpanan dan pengolahan data saat ini adalah Ms Office, dimana data-data yang diolah antara lain daftar pendidik dan tenaga kependidikan, daftar peserta didik dan data nilai siswa. Penyimpanan dan pengolahan data seperti yang disebutkan diatas mengakibatkan sering ditemukannya kendala dalam urusan administrasi akademik oleh pihak sekolah. Pengolahan data siswa, pencarian dokumen ataupun berkas siswa memakan waktu yang cukup lama dan sering ditemukan data yang tidak konsisten karena media penyimpanannya yang belum tersentralisasi.

Berdasarkan permasalahan tersebut maka penulis ingin membuat sebuah Sistem Informasi yang memanfaatkan teknologi web yaitu "Sistem Informasi Akademik Pada SMP Negeri 1 SOEBerbasis Web "guna membantu dalam proses pengolahan data.

\section{METODE PENELITIAN}

Tahapan proses metodologi penelitian yang dilakukan dalam penelitian ini terdapat pada gambar berikut: 


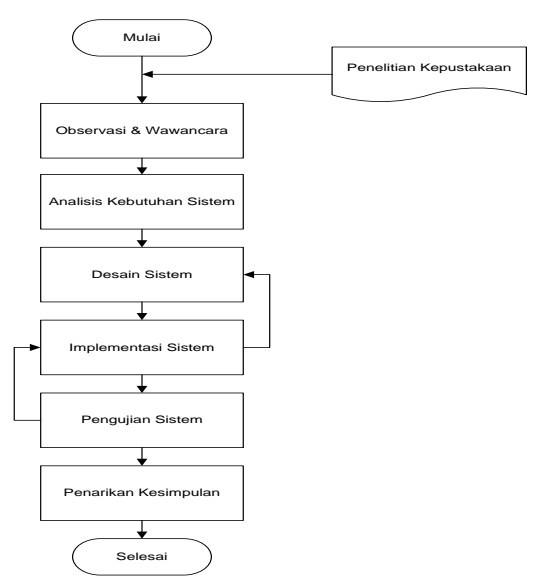

Gambar 1. Flowchart metodologi penelitian

Berdasarkan flowchart diatas, langkah pertama adalah mengumpulkan data.Dalam mengumpulkan data, penulis melakukan penelitian kepustakaan, observasi dan wawancara.Penulis melakukan pengamatan langsung dan melakukan wawancara di SMP Negeri 1 Soe untuk memperoleh data yang diperlukan.Penulis juga melakukan penelitian kepustakaan dimana penulis mencari referensi dalam mengembangkan sebuah sistem informasi akademik.

A. Analsis Kebutuhan Sistem

Data yang telah terkumpul dianalisis untuk mendapatkan data yang dibutuhkan dalam membangun sistem informasi akademik SMP Negeri 1 Soe. Kebutuhan input yang diperlukan dalam pembuatan sistem informasi akademik pada SMP Negeri 1 Soe adalah data guru, data siswa/i, data nilai siswa/i, data kelas, data wali kelas, data mata pelajaran, dan data jadwal mata pelajaran. Semua data input akan diproses dan menghasilkan output berupa informasi mengenai data guru, data siswa/i, data nilai siswa/i, data kelas, data wali kelas, data mata pelajaran, dan data jadwal mata pelajaran.

B. Desain Sistem

1. Diagram konteks

Berikut ini adalah rancangan diagram konteks sistem informasi akademik pada SMP Negeri 1 Soe:

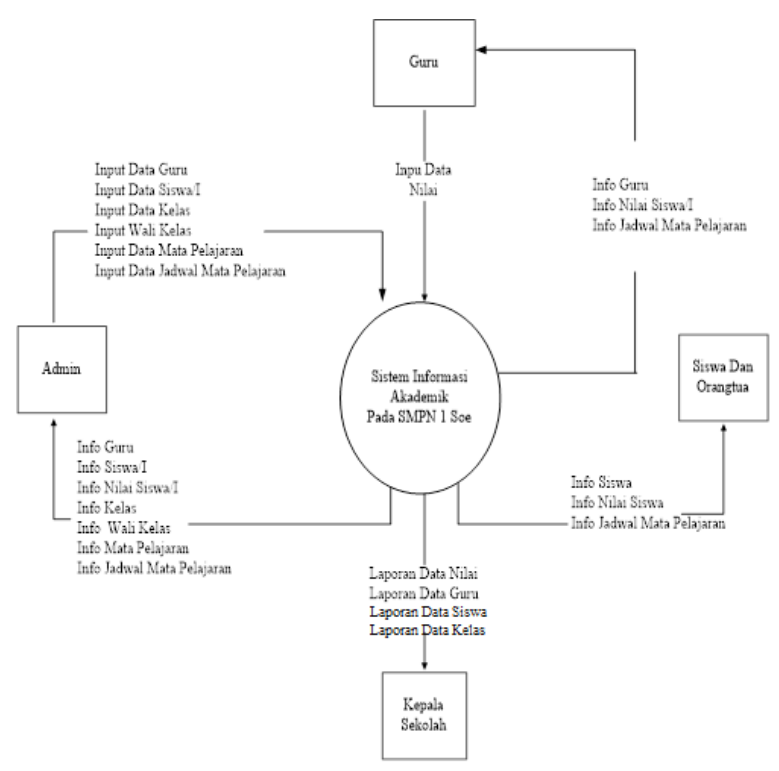

Gambar 2. Diagram KonteksSistem Informasi Akademik SMP Negeri 1 Soe Berbasis Web

Pengguna sistem informasi akademik SMP Negeri 1 Soe adalah admin, guru, siswa dan orangtua, serta kepala sekolah.

- Admin menginput data guru, data siswa/i, data kelas, wali kelas, data mata pelajaran, dan jadwal mata pelajaran. Admin bisa melihat kembali data yang sudah diinput dalam bentuk informasi.

- Guru menginput data nilai siswa, dan dapat melihat info data guru, info data nilai siswa, dan info jadwal mata pelajaran.

- Siswa dan orangtua dapat melihat info data siswa, info nilai siswa, dan info jadwal mata pelajaran

- Kepala sekolah dapat melihat laporan data nilai, laporan data kelas, laporan data siswa, laporan data mata pelajaran, dan laporan data guru

2. DFD (Data Flow Diagram)

DFD dalam membangun sistem informasi akademik pada SMP Negeri 1 Soe adalah sebagai berikut: 
Panggalo $^{1 *}$, Bire $^{2}$, Laran $^{3}$

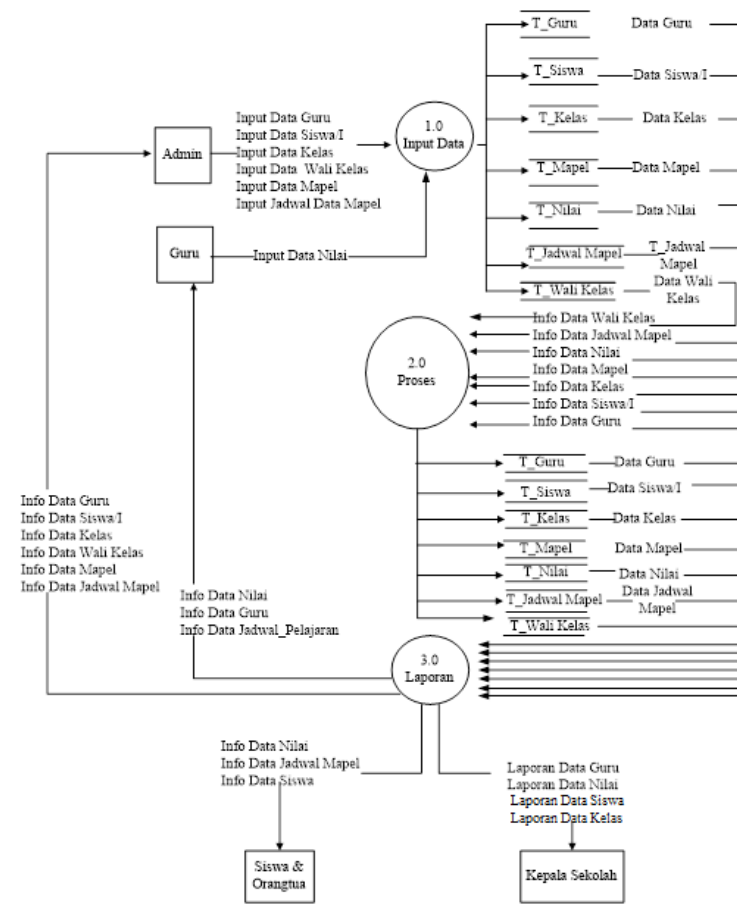

Gambar 3. DFD Sistem Informasi Akademik SMP Negeri 1 Soe Berbasis Web

3. ERD (Entity Diagram Relationship)

Berikut ini adalah ERD yang menunjukkan hubungan antara tabel pada perancangan sistem informasi akademik pada SMP Negeri 1 Soe:

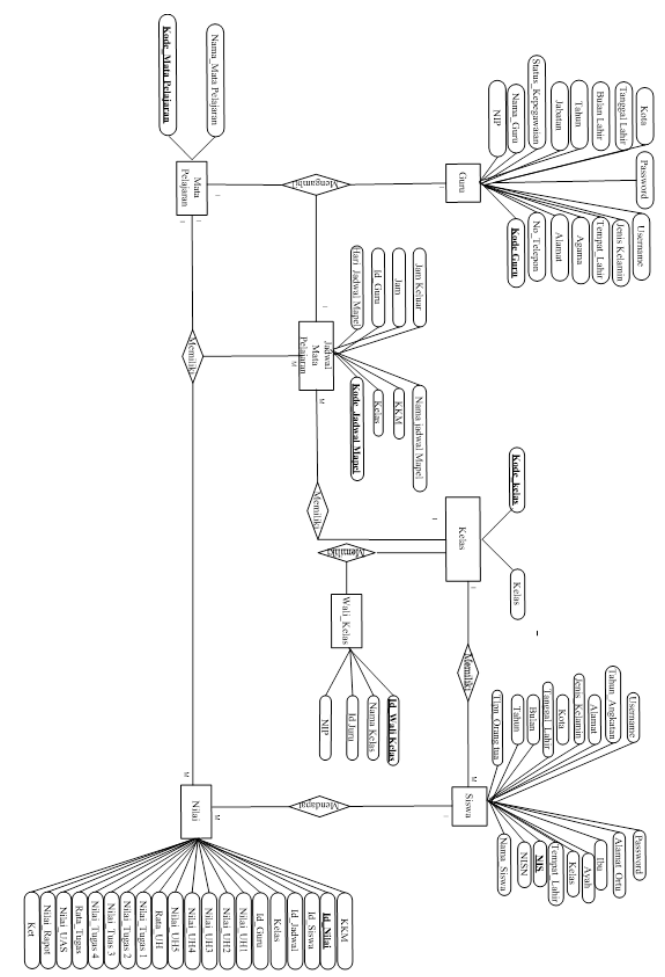

Gambar 4. ERD

C. Implementasi Sistem

Pada tahap implementasi sisstem, penulis menuliskan codding untuk membangun Sistem Informasi Akademik SMP Negeri 1 Soe berdasarkan desain sistem pada tahap sebelumnya.Web server yang digunakan adalah Xampp, dengan web editor notepad++ dan Phpdesigner8.

D. Pengujian Sistem

Pada tahap ini, penulis melakukan pengujian yang menghasilkan kebenaran program. Proses pengujian berfokus pada logika internal perangkat lunak. Pengujian sistem memastikan bahwa semua penginputan, proses, dan output sesuai dengan yang diharapkan.

\section{HASIL DAN PEMBAHASAN}

A. Login

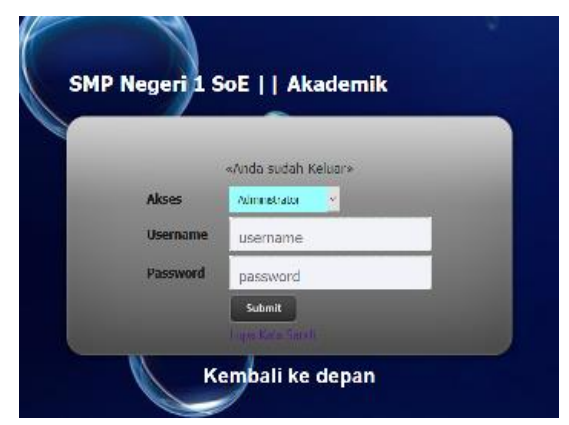

Gambar 5.Halaman index

Halaman index berisikan form login bagi pengguna website. Setiap pengguna website memasukan username dan password untuk masuk ke dalam sistem.

\section{B. Admin}

Setelah admin berhasil login, maka admin akan diarahkan ke halaman HomeAdmin. Pada tampilan sistem untuk admin terdapat beberapa menu yaitu menu home, menu setting, menu management data, menu guru, menu penjadwalan dan menu laporan.

1. Home

Jika admin memilih menu Home, maka sistem akanmenampilkan halaman Home. Homemerupakan beranda bagi admin. 


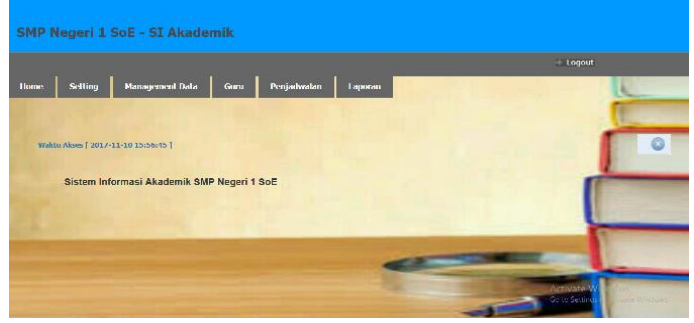

Gambar 5.Tampilan HomeAdmin

\section{2. $\quad$ Setting}

Pada menu setting terdapat dua submenu yaitu Admin dan Sekolah.Pada halaman Admin terdapat form tambah data admin untuk menambah, mengunah, dan menghapus data admin. Halaman Sekolah merupakan halaman untuk mengelola data sekolah yang terdapat tombol edit untuk mengubah data sekolah.

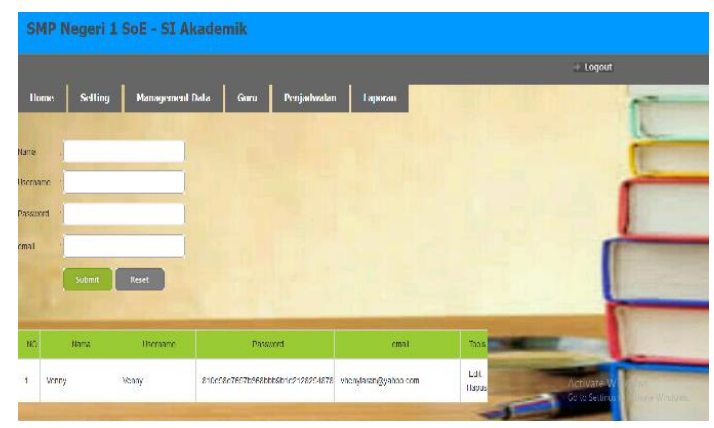

Gambar 6.Tampilan Tambah Data Admin

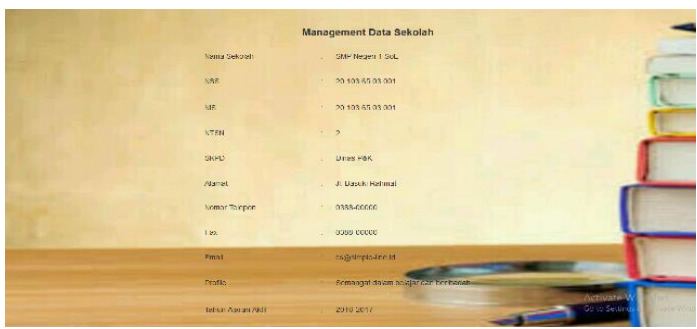

Gambar 7.Tampilan Data Sekolah

3. Management Data

Pada menu management data terdapat tiga submenu yaitu Data Siswa, Data Kelas, dan Data Pelajaran.

Jika admin memilih submenu Data Siswa, maka sistem akanmenampilkan halaman Data siswa. Pada halaman Data Siswa terdapat beberapa tombol yang dapat digunakan oleh admin seperti tombol tambah data siswa yang berfungsi untuk menambah data siswa baru, tombol pencarian untuk melihat data siswa berdasarkan kelas dan nis, tombol edit data untuk mengubah data siswa, dan tombol hapus data untuk menghapus data siswa.

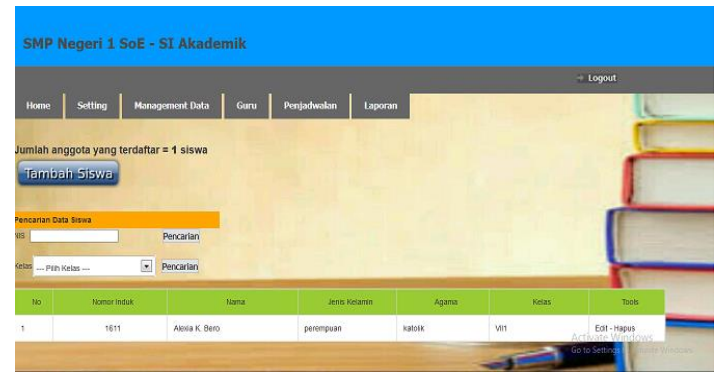

Gambar 8. Tampilan Data Siswa

Pada halaman Tambah Data Siswa, terdapatpilihan kelas yang akan ditempati oleh siswa yang bersangkutan dimana data kelas tersebut diperoleh dari tabel kelas.

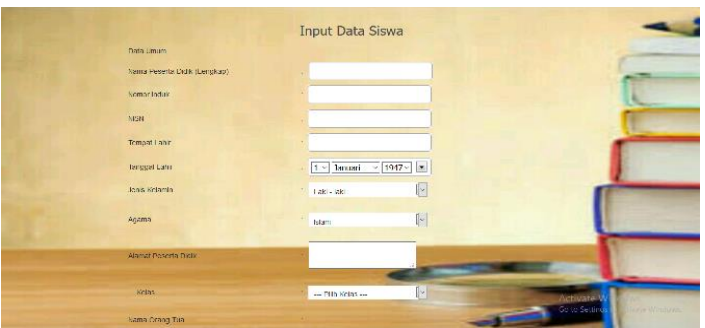

Gambar 9.Tampilan Tambah Data Siswa

Jika admin memilih submenu Data Kelas, maka sistem akanmenampilkan halaman Data Kelas. Pada halamanData Kelas terdapat beberapa tombol yang dapat digunakan oleh admin seperti tombol tambah data yang berfungsi untuk menambah data kelas baru, tombol edit data untuk mengubah data kelas, dan tombol hapus data untuk menghapus data kelas.

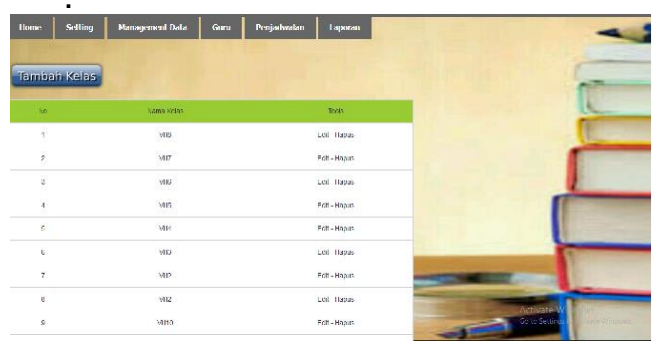

Gambar 10. Tampilan Data Kelas 
Panggalo $^{1 *}$, Bire $^{2}$, Laran $^{3}$

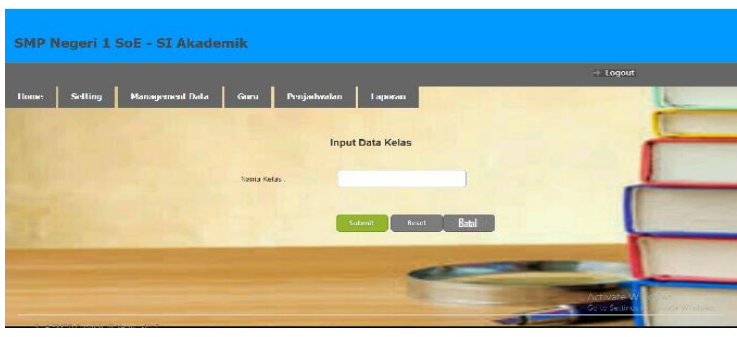

Gambar 11.Tampilan Tambah Data Kelas

Jika admin memilih submenu Data Mata Pelajaran, maka sistem akanmenampilkan halaman Data Mata Pelajaran. Pada halamanData Mata Pelajaran terdapat beberapa tombol yang dapat digunakan oleh admin seperti tombol tambah data yang berfungsi untuk menambah data mata pelajaran baru, tombol edit data untuk mengubah data mata pelajaran, dan tombol hapus data untuk menghapus data mata pelajaran.

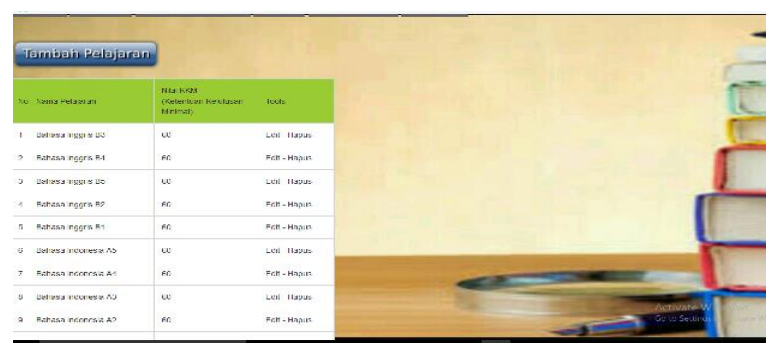

Gambar 12. Tampilan Data Mata Pelajaran

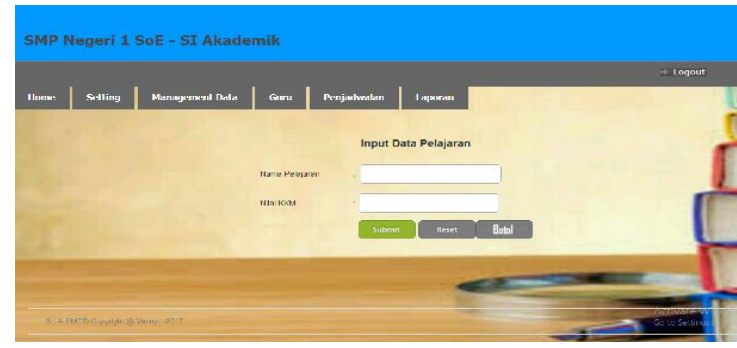

Gambar 13. Tambah Data Mata Pelajaran

4. Guru

Jika admin memilih menu Guru, maka sistem akan membuka halaman Data Guru. Padahalaman Data Guru, terdapat beberapa tombol yang dapat digunakan oleh admin seperti tombol tambah data guru yang berfungsi untuk menambah data guru baru,tombol edit data untuk mengubah data guru, dan tombol hapus data untuk menghapus data guru.

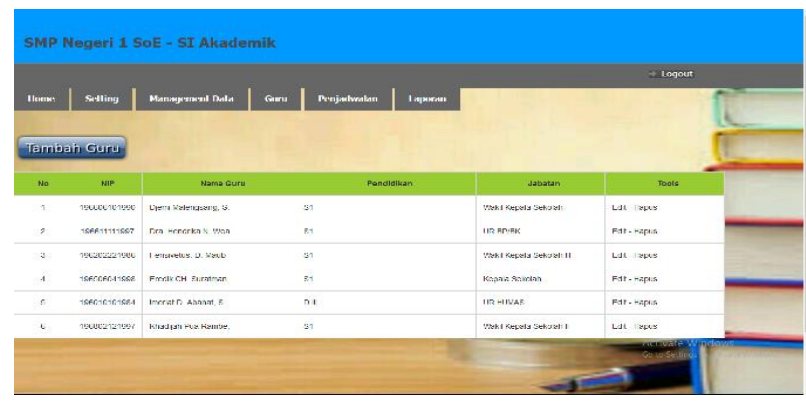

Gambar 14. TampilanData Guru

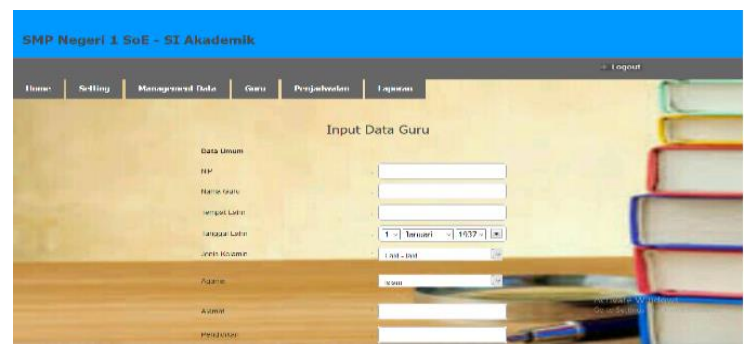

Gambar 15.Tampilan Tambah Data Guru

5. Penjadwalan

Pada menu Penjadwalan terdapat dua submenu yaitu Wali Kelas dan Pengajaran.Jika admin memilih submenu Wali Kelas, maka sistem akanmenampilkan halaman Data Wali Kelas. Pada halaman Data Wali Kelas, admin memasukan data sesuai dengan yang telah disediakan sistem.

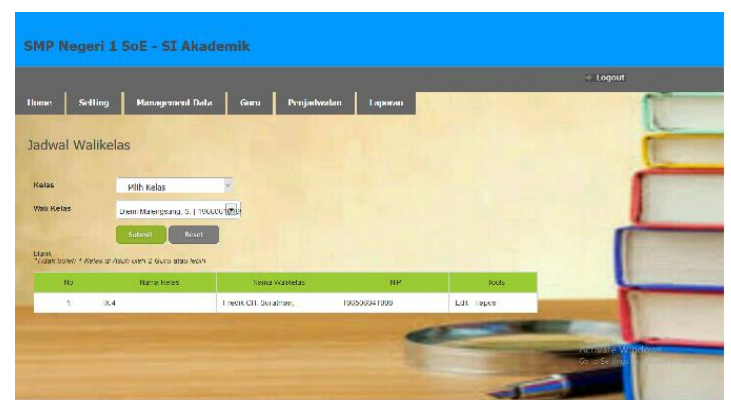

Gambar 16. Tampilan Data Wali Kelas

Jika admin memilih submenu Data

Pengajaran, maka sistem akanmenampilkan halaman Data

Pengajaran. Pada halaman Data Pengajaran, admin memasukan data sesuai dengan yang telah disediakan sistem. Setelah datapengajaran tersimpan, data pengajaran akan ditampilkan sebagai jadwal mata pelajaran. 


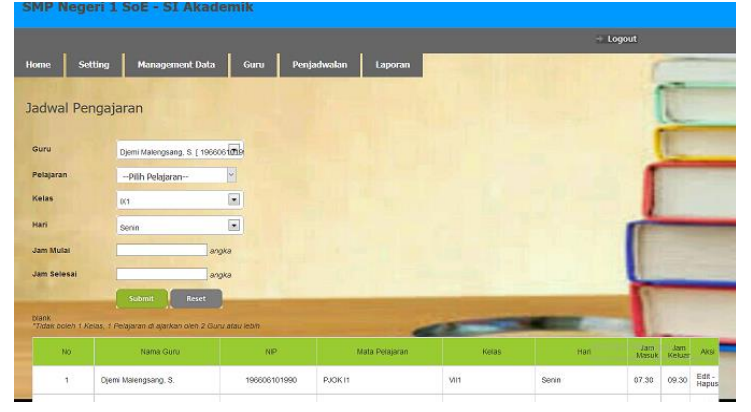

Gambar 17. Tampilan Jadwal Mata Pelajaran

6. Menu Laporan

Pada menu laporan terdapat lima submenu yaitu LaporanData Nilai, Laporan Data Kelas, Laporan Data Siswa, Laporan Data Mata Pelajaran dan Laporan Data Guru.Jika admin memilih submenu laporan data nilai, maka sistem akanmenampilkan halaman berisi laporan nilai.Admin dapat memilih mata pelajaran yang tersedia maka akan ditampilkan laporan nilai berdasarkan mata pelajaran yang dipilih.

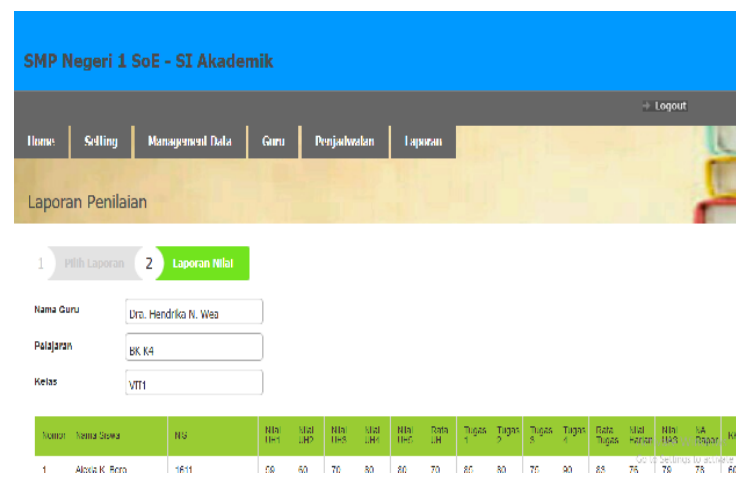

Gambar 18. Tampilan Laporan Data Nilai

Jika admin memilih submenu Laporan Data Kelas, sistemakanmenampilkan halaman Laporan Data Kelas.

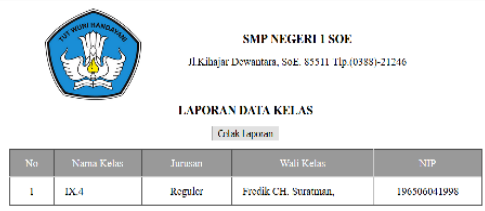

Kelas

Gambar 19.Tampilan Laporan Data

Jika admin memilih submenu Laporan
Data Siswa, maka sistem akan menampilkan halaman Laporan Data Siswa. Pada halaman Laporan Data Siswa,terdapat tombol cetak untuk mencetak seluruh data siswa maupundata siswa perkelas.

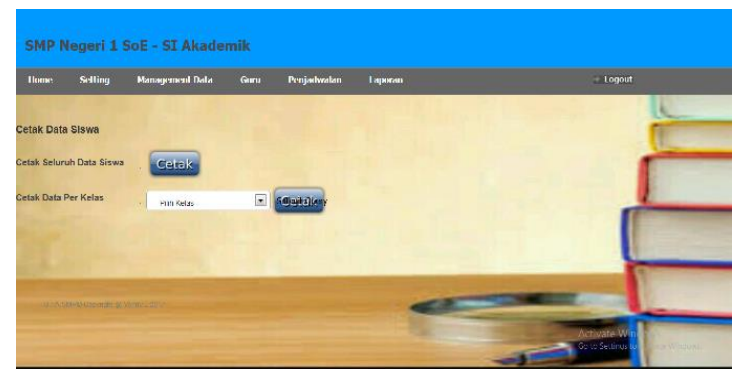

Gambar 20.Tampilan Laporan Data Siswa

Jika admin memilih submenu Laporan Data Mata Pelajaran, maka sistem akanmenampilkan halaman Laporan Data Mata Pelajaran.

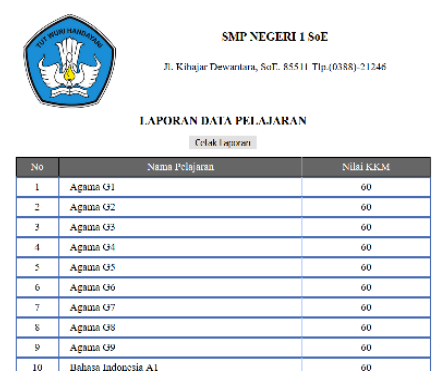

Gambar 21.Tampilan Laporan Mata Pelajaran

Jika admin memilih submenu Laporan Data Guru, maka sistem akan menampilkan halaman Laporan Data Guru.

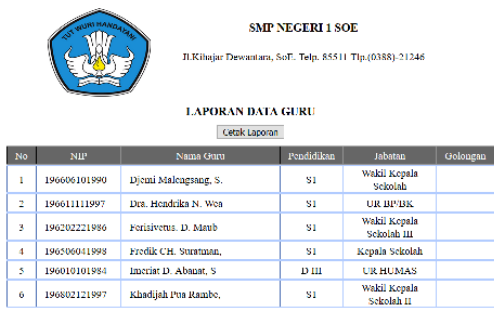

Gambar 22.Tampilan Laporan Data Guru

C. Guru

Setelah guru berhasil login, maka guru akan diarahkan ke halaman homeguru. Pada tampilan ssistem untukguru terdapat beberapa 
menu yaitu Home, Jadwal Mengajar, Input Nilai, Laporan Penilaian, dan Biodata Guru .

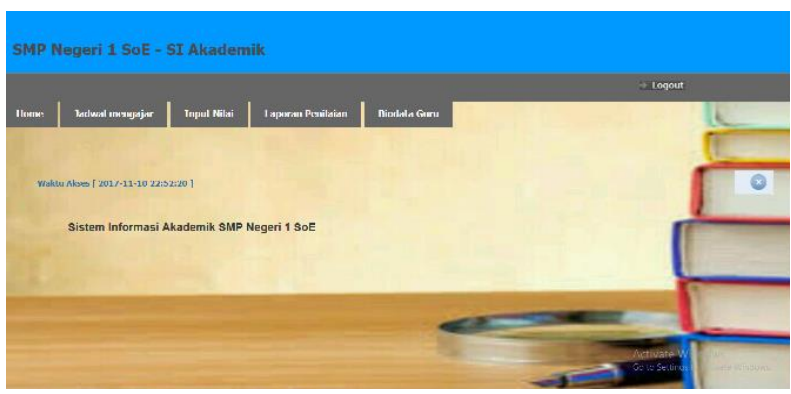

Gambar 23. Home Guru

1. Home

Home merupakan beranda bagi guru.

2. Jadwal mengajar

Menu

Jadwal

Mengajarmenampilkanjadwal mengajar bagi guru.

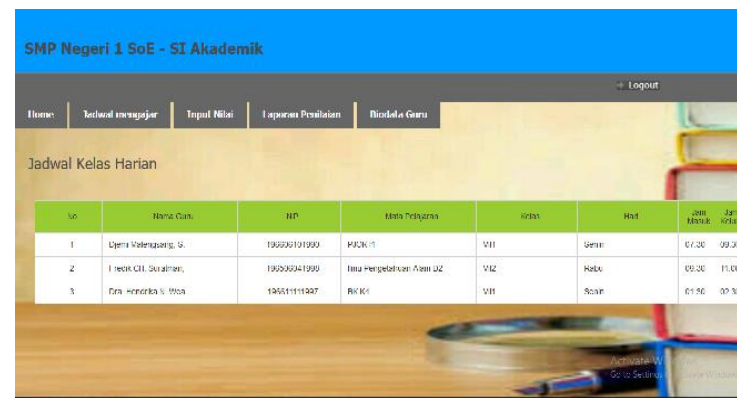

Gambar 24. Tampilan Jadwal Mengajar Guru

3. Input Nilai

Pada Input Nilaiterdapat form pengisian nilai untuk guru yang mengajar pelajaran yang ada. Pada menu ini, apabila ingin menginput nilai, harus memilih mata pelajaran terlenih dahulu lalu masuk ke form input nilai.Pada halaman ini terdapat tombol update untuk mengubah nilai yang telah diinput.

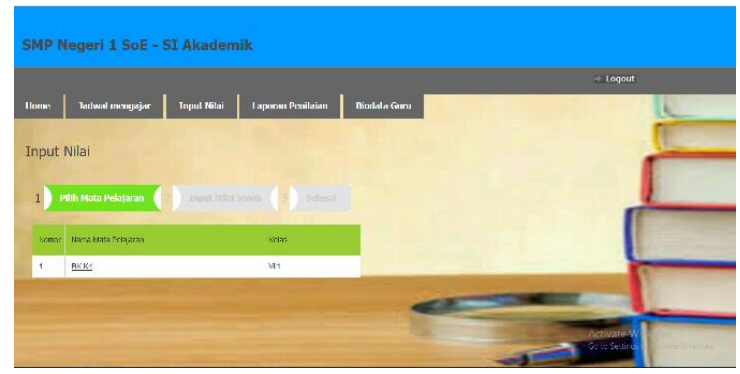

Gambar 25. Tampilan pilih mata pelajaran

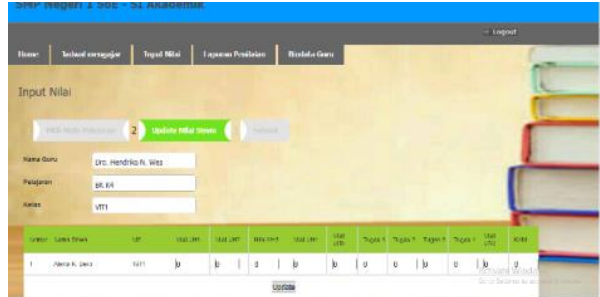

Gambar 26. Tampilan Input Nilai

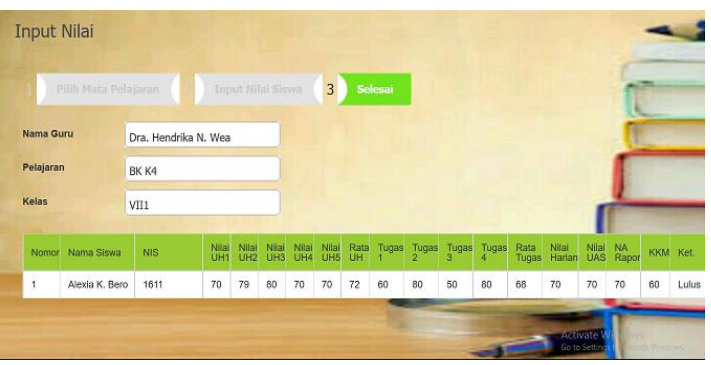

Gambar 27. Tampilan Hasil Input Nilai

4. Biodata Guru

Jika guru memilih menu Biodata Guru, maka sistem akan membuka halaman Biodata Guru yang berisi identitas guru.

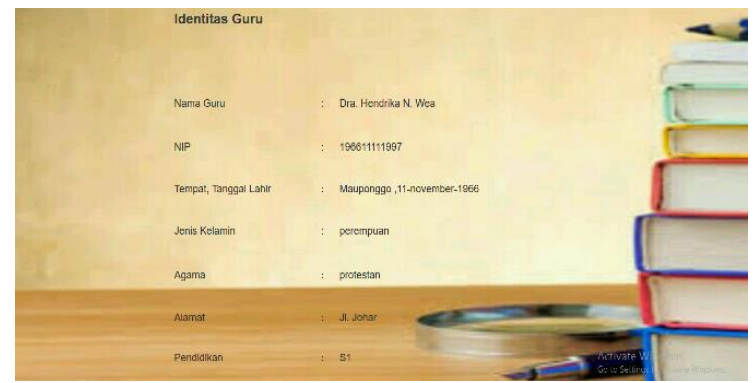

Gambar 28. Tampilan Biodata Guru

D. Siswa/ Orangtua Siswa

Setelah siswa atau orang tua siswa berhasil login, maka siswa akan diarahkan ke halaman home siswa. Pada tampilan sistem untuk siswa, terdapat beberapa menu yaitu menu Home, Jadwal Pelajaran, Hasil Nilai, dan Biodata Siswa.

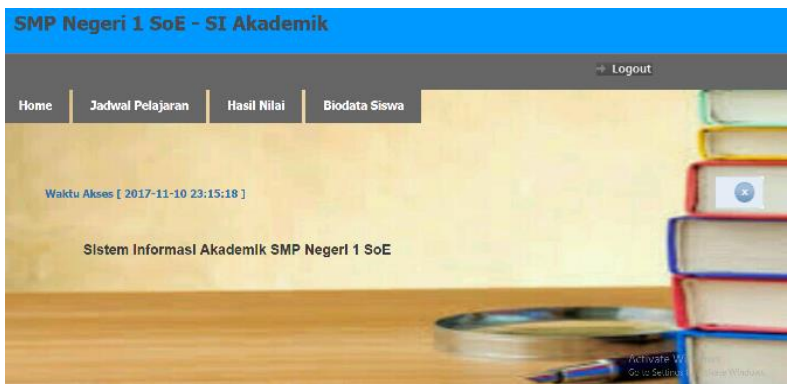




\section{Gambar 29. Tampilan Home Siswa}

Home merupakan beranda bagi siswa, sedangkan Jadwal Pelajaran merupakan tampilan jadwal pelajaran bagi siswa.

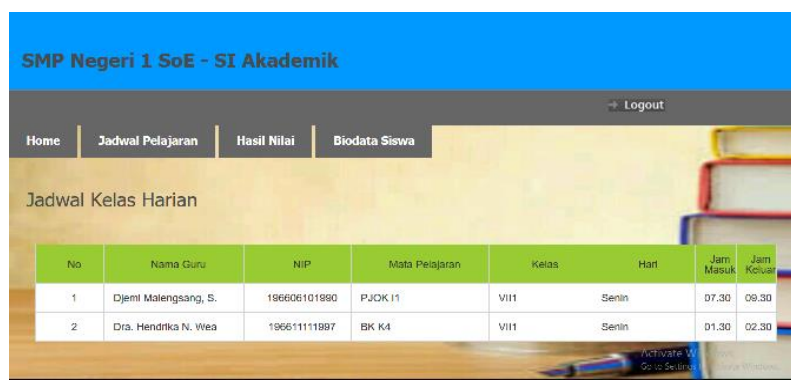

Gambar 30. Tampilan Jadwal Pelajaran

Jika siswa memilih menuHasil Nilai, maka sistemakan menampilkan halaman nilai untuk siswa.

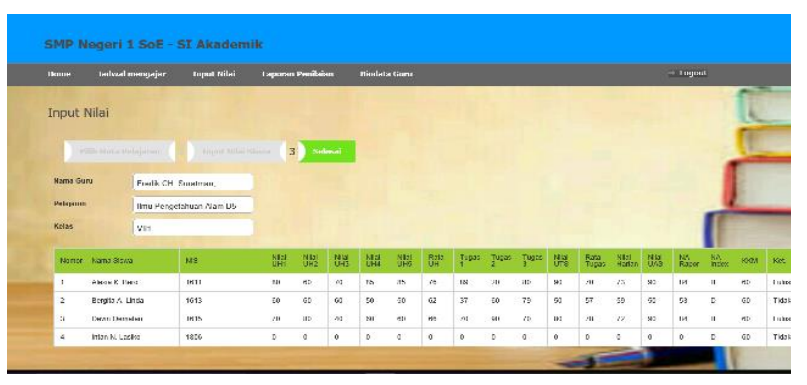

Gambar 31. Tampilan Hasil Nilai Siswa

Jika siswa memilih menu Biodata siswa, maka sistem akan menampilkan halaman identitas siswa.

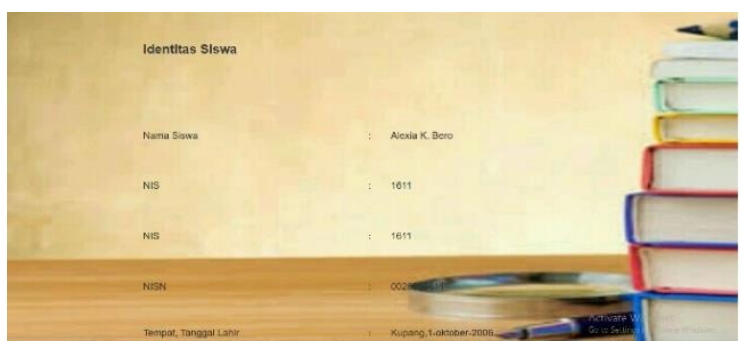

Gambar 32. Tampilan biodata siswa

\section{PENUTUP}

A. Kesimpulan

Setelah membangun Sistem Informasi Akademik SMP Negeri 1 Soe Berbasis Web, maka diperoleh kesimpulan sebagai berikut:

1. Sistem Informasi Akademik SMP Negeri 1

Soe berhasil dibuat menggunakan PHP dan MySql.

2. Sistem ini mampu melakukan pengelolan dan menampilkan data guru, data siswa/i, data nilai siswa/l, data kelas, data wali kelas, mata pelajaran dan jadwal pelaran beserta laporan.

3. Sistem mampu menampilkan dan mencetak nilai rapot tiap siswa.

4. Sistem mampu melakukan penambahan kelas baru untuk tahun ajaran baru.

B. Saran

Dalam membangun sistem ini, disadari masih banyak kekurangan dan kelemahan. Oleh karena itu terdapat beberapa saran untuk pengembangan selanjutnya sebagai berikut:

1. Agar kedepan sistem informasi ini dapat ditambahkan fitur kegiatan ekstrakurikuler yang diminati tiap siswa.

2. Selain itu dapat juga dilakukan pengembangan menambahkan menu materi pelajaran maupun bahan ajar yang bisa didownload oleh siswa.

\section{UCAPAN TERIMAKASIH}

Pembangunan Sistem Informasi Akademik pada SMP Negeri 1 Soe berbasis Web tidak akan selesai tanpa bantuan berbagai pihak. Oleh karena itu, penulis mengucapkan terima kasih kepada pihak sekolah SMP Negeri 1 Soe yang telah bersedia memberikan kesempatan kepada penulis dan timuntuk melakukan penelitian dan memberikan data yang diperlukan.Penulis juga mengucapkan terima kasih kepada rekanrekan peneliti, karena kerja sama tim yang baik sehingga mampu menyelesaikan penelitian ini.

\section{DAFTAR PUSTAKA}

Brady,M.,\& Loonam, J. 2010. Exploring the use of entity-relationship diagramming as a technique to support grounded theory inquiry. Bradford: Emerald Group Publishing.

Davis Gordon, B. 1991.Kerangka Dasar Sistem Informasi Manajemen.Jakarta.

Indrajit, 2001.Analisis dan Perancangan Sistem Berorientasi Object.Bandung 
Jogiyanto, H.M. 2005, Analisa dan Desain Sistem Informasi: Pendekatan Terstruktur Teori dan Praktik Aplikasi Bisnis, Andi, Yogyakarta.

Ledorf, Rasmus. 2006. Programming PHP.London:O'Reily Media

Murdick, R. G. 1991. Sistem Informasi Untuk Menajemen Modern, Jakarta: Erlangga.

Pressman, Roger S. 2012.Rekayasa Perangkat Lunak - Buku Satu, Pendekatan Praktisi (Edisi 7). Yogyakarta: Andi.

Sidharta, Lani. 1995. Pengantar Sistem Informasi Bisnis, PT. Elex Media Komputindo, Jakarta. 